\title{
É POSSÍVEL FAZER TELEVISÃo PÚBLICA NO BRASIL?*
}

\author{
EUGÊNIO BUCCI
}

[*] Para a finalização deste texto, foi providencial a revisão atenta de Felipe Marques, quem também apoiou o autor na pesquisa.

Comecemos por um lugarcomum (lembrando queessa expressão, lugar comum, não por acaso, pode designar também lugar de todos, ou mesmo "espaço público"), subdivido em duas metades indissociáveis, imprescindíveis uma à outra.

Primeira metade: Quando subordinada à orientação da autoridade estatal, a emissora pública não é pública de fato; sua linha editorial, sua programação e sua visão de mundo tendem a ser capturadas pela óptica estatal ou governamental, o que a distancia irreversivelmente dos pontos de vista próprios da sociedade civil. A subserviência ao poder público, nesse caso, mais do que nociva, é mortal. Impede a emissora de transmitir um olhar crítico em relação ao poder.

Não custa partir do óbvio. Por que a sociedade sustenta uma entidade prestadora de serviço público? Porque a atividade que essa entidade desenvolve corresponde a um direito da cidadania. Universidades ou escolas públicas justificam-se porque atendem o direito à educação. Hospitais públicos, por garantiro acesso do cidadão à saúde e aos tratamentos e cuidados a que tem direito. Uma emissora pública existe porque as pessoas têm direito (como autoras, agentes ou espectadoras) à informação jornalística, ao conhecimento e às manifestações culturais.

Quanto à informação jornalística, a emissora pública é um posto avançado daquilo que o cidadão tem direito a perguntar e demandar, não daquilo que o poder gostaria de difundir. $O$ vetor que orienta a existência das emissoras públicas nasce na sociedade, nos direitos de homens e mulheres que são a fonte do poder, e aponta para o Estado e para o governo como quem lhes dirige perguntas. Nessa fórmula, as autoridades são polos passivos, entram em cena quando inquiridos. As emissoras públicas, em suma, existem para ajudar a sociedade a realizar o ideal da imprensa - que é instituição social, independente do Estado, em que vige a liberdade de expressão, incumbida de fiscalizar o poder. Elas só têm sentido social e histórico se estiverem a serviço da sociedade e dos direitos dos cidadãos. Quando servem ao governo e às suas necessidades de propaganda, são uma deformação que nega a razão de sua origem. 
Segunda metade: Nenhuma emissora pública pode ser assim chamada se está subordinada ao mercado. Esse foi o modelo adotado no Chile.Administrativamente pode dar certo, as contas fecham. No que mais interessa, porém, não dá certo. A TVN (Televisión Nacional de Chile) é pública apenas por ser patrimônio público, mas opera como se fosse uma emissora comercial qualquer. Por isso assume a fisionomia de uma televisão comercial como as demais. Não faz exatamente radiodifusão pública; oferece um cardápio de programas que misturam humor, notícias, esportes, como uma rede privada ${ }^{1}$.

Uma estação de rádio ou TV que não seja propriedade particular certamente não é propriedade privada, como outras tantas. Portanto, trata-se de uma propriedade mais ou menos pública. Mas, se sua receita ordinária vem de anúncios, ela funciona como uma emissora comercial. Sua única distinção em relação às demais será apenas sua natureza jurídica. Na prática, porém, adotará um comportamento típico de emissora comercial. Nesse sentido, a programação da TVN, de Santiago do Chile, é sintomática².

Quando depende de verbas publicitárias, um canal de TV ou de rádio não tem como escapar de estruturar sua grade de programação segundo a lógica e o ritmo dos intervalos comerciais. Isso acarreta efeitos estéticos e éticos. Sua cadência, por assim dizer, iguala-se aos canais comerciais; o andamento fica idêntico, assim como a linguagem e os códigos audiovisuais.

Quando se sustenta por meio de publicidade, a emissora passa a prestar contas aos anunciantes, aos quais oferece retorno em forma do consumo incentivado pelas campanhas que veicula. Assim, ainda que não se subordine ao poder político ou estatal, ela se desequilibra na direção oposta: subordina-se ao mercado, às suas predileções, modulações, e perde a capacidade de levar ao ar um olhar crítico em relação ao consumo e às crenças próprias do mercado. Em suma, deixa de ser pública.

\section{INDEPENDÊNCIA SEM ARROGÂNCIA}

Seja no plano político (relações com o governo e o Estado), seja no plano econômico (relações com o mercado), a independência é indispensável para a realização de qualquer projeto de radiodifusão pública. "Independência" não deve ser entendido, no entanto, como "arrogância". Em tempos devalorização da noção de interdependência, envolta em fetiches, incensada pelo presente contexto global,é preciso uma certa cautela ao se pregar a independência. Atualmente, o desafio ético é aprender a conviver em um ambiente onde não existe mais a possibilidade do isolamento absoluto de nenhum ator, país ou comunidade.
[1] Vale a pena consultar a Lei 19.132, promulgada no Chile em 30 de março de 1992, que criou a TVN (ver <httt:// www.tvn.cl/corporativo/2010/marconormativo.html ). Segundo o artigo 25, a TVN fica impedida de receber qualquer aporte de dinheiro público. Tudo em seu funcionamento é decorrente das regras de mercado, inclusive a veiculação de publicidade comercial. Na prática, trata-se de uma emissora comercial. Não obstante, todas as suas contas estão disponíveis no site da emissora, incluindo a remuneração dos dirigentes (ver <http:// www.tvn.cl/corporativo/2010/remuerajec.html >). Nesse caso, o procedimento é um ótimo exemplo para emissoras que se pretendam públicas em qualquer parte do mundo.

[2] Agrade e os programas estão disponiveis em 〈www.tvn.cl〉. São atrações de auditório, jornadas esportivas comerciais, programas de humor etc. voltados fundamentalmente a disputar os maiores nacos de audiência e, com isso, ser capaz de competir com as emissoras comerciais. Isso não quer dizer que emissoras públicas não disputem audiência. Elas disputam, mas com um propósito essencialmente crítico. 
Independência, portanto, não é isolamento, mas autonomia de critérios de decisão e de procedimentos. É o distanciamento crítico em relação ao poder político ou estatal e em relação ao mercado. De modo algum implica uma postura de autossuficiência ética, cultural e jornalística. A emissora pública não deve prestar contas ao governo nem ao capital, mas isso justamente porque as presta, recorrentemente, ao público e à sociedade. A independência em relação ao poder (governamental ou econômico) é pré-requisito para a interdependência da emissora pública em suas relações com a sociedade.

Mesmo para os entusiastas da interdependência como valor universal - entusiasmo de que o presente artigo não compartilha -,é indispensável a premissa da independência, pois só são interdependentes aqueles que sabem preservar sua própria independência. O termo independência, enfim, não se contrapõe ao termo interdependência, mas é antônimo de dependência - e dependência do poder.

Quanto a isso, sejamos cuidadosos. Em nome da interdependência, essa expressão palatável e muito em voga, todo tipo de sujeição tem sido imposta a emissoras públicas no Brasile, de modo geral, em toda a América Latina. Se o canal que se diz público é gerido por gente escolhida direta ou indiretamente pelo governador ou pelo presidente da República, o que resulta não é "interdependência”, mas dependência explícita. Um canal como esse não corresponde aos ideais da comunicação pública. Do mesmo modo, quando sua sobrevivência depende de recursos vindos dos anunciantes, a emissora que se diz pública também não é independente e, nesse sentido, não realiza a razão de ser da comunicação pública.

\section{O CARÁTER PÚBLICO NA TRADIÇ̃̃o EUROPEIA}

As emissoras públicas foram criadas para proteger a vitalidade dos debates e das manifestações culturais que a sociedade deve pautar, produzir e entabular em seu domínio civil próprio, independentemente do Estado e também do mercado. Há variações de país para país, mas o fundamento político é o mesmo. E com razão.

A Europa de meados do século XX, onde ganhou concretude o projeto das emissoras públicas, ainda hoje nos serve de referência. Quando a social-democracia europeia decidiu prover o serviço de radiodifusão (definido como serviço público em quase todos os países democráticos) por meio das redes públicas (não comerciais, portanto), o seu propósito era assegurar a proteção do debate público. Em termos habermasianos, que consolidam em forma de teoria essa visão, o projeto era assegurar que os atores convidados a atuar dialogicamente na esfera pública não estivessem (tão) expostos à colonização pelo capital ou mesmo pelo Estado. Com isso, o fluxo das notícias e os diálogos teriam como pressuposto a igualdade de condições de acesso à informação. 
Naqueles tempos, meados do século XX, tomava corpo a utopia da comunicação pública: as emissoras não comerciais e não governamentais protegeriam a esfera pública. A radiodifusão comercial, se tomasse conta do espectro, era vista por esse projeto como um fator de risco. Dessa concepção brotaram as redes públicas nacionais de televisão e rádio nas diversas democracias europeias, que perduraram por um longo ciclo sem maiores abalos. Pelo menos até meados da década de 1980 , a fatia mais importante da radiodifusão nesses países ainda era controlada pelas instituições públicas. Mais tarde, alguns canais foram privatizados e, estabeleceu-se a partir de então um novo equilíbrio entre emissoras públicas e comerciais. Até hoje, as primeiras ocupam lugar de destaque e, não raro, de liderança, nos rankings de audiência.Mas, de qualquer maneira, a mentalidade nesses países sofreu um deslocamento, incorporando a ideia de que a comunicação comercial também não poderia faltar na ordem democrática; a convivência entre os sistemas público e comercial seria bem mais saudável do que o monopólio do primeiro.

As privatizações, contudo, não afetaram as bases da convicção, ainda hoje dominante entre intelectuais de diferentes tendências, de que só se pode falar genuinamente de esfera pública se esta for mediada, ainda que não exclusivamente, pelas redes públicas, com regras que protejam as simetrias dialógicas e as culturas nacionais contra as distorções do mercado. Essa convicção baseia-se no princípio de que os bens culturais e a informação de interesse público não se esgotam em sua dimensão de mercadoria. Não são apenas mercadoria.

$\mathrm{Na}$ França, a reserva de mercado para o cinema nacional tem sido praticamente uma unanimidade entre as forças políticas, da direita à esquerda. Ou os bens culturais são relativamente preservados por medidas de ordem pública, ou a própria cultura seria devastada por pressões dos mercados. Com as emissoras públicas, o raciocínio tem sido mais ou menos o mesmo. Se os meios públicos de comunicação (estatais ou não, mas fundamentalmente não comerciais) dão o quadro da comunicação social, o espaço público é menos vulnerável a pressões do poder (econômico ou governamental)eé, portanto, mais democrático e inclusivo.

Por isso, até hoje as redes públicas têm forte presença nos países europeus, ainda que seu prestígio venha declinando. Esse declínio se deve, em primeiro lugar, às barbeiragens reincidentes da má gestão, o que gerou estruturas perdulárias e ineficientes em boa parte dessas emissoras, e, em segundo lugar, às controvérsias sobre a pertinência (ou não) de vultosos investimentos em emissoras cuja eficiência e necessidade vêm sendo postas em questão3.
[3] A Radio Televisión Española (RTVE) alcançou, ao final de 2005 , uma dívida de 7,5 bilhões de euros (ver 〈http://www.libertaddigital. com/economia/la-deuda-de-rtve-supera-los-750o-millones-de-euros-al-cierre-del-ejercicio-de-2005$1276272097 />)$. Em setembro de 2006 , a dívida chegou a 7,8 bilhões de euros e foi noticiado que o $\mathrm{Te}$ souro Público assumiria o débito (ver < http://terranoticias.terra.es/ articulo/html/av21111055.htm〉). Em 2010, a dívida ultrapassou a casa dos 16 bilhões de euros, e o debate em torno das formas de quitá-la não se concluiu. Em Portugal, a RTP vive um desgaste que passa pelo questionamento, há vários anos, dos custos da emissoroa e de altos salários pagos aos executivos da instituição. Ver, por exemplo, "Só com a RTP o Estado gasta 400 milhões de euros", em 〈http://diario.iol.pt/politica/orcamento-tvi24-universidade-aberta-psd-ultimas-passos-coelho/1189535-4072.html >. Outro fato marcante foi o corte, anunciado pelo governo britânico no financiamento dos serviços da BBC Internacional. Tradicionalmente custeados pelo Estado, esses serviços passarão a ser debitados à própria $\mathrm{BBC}$. Ver "Governo corta recursos da BBCWorld", em 〈http://wwwl.folha.uol.com.br/fsp/ mercado/me2110201037.htm >. 
[4] Conferir a declaração de objetivos da FCC para 2009-2014 em 〈http://hraunfoss.fcc.gov/edocs public/attachmatch/doc-285705Al. pdf $>$

\section{A TRADIÇÃo AMERICANA}

Também nos Estados Unidos, embora a matriz da radiodifusão tenha se baseado muito mais no modelo comercial, deu-se a adoção de regras públicas bem assertivas, com o objetivo de proteger os mesmos valores. Esse dado normalmente não é percebido por quem se interessa pela história das emissoras públicas, mas também nos Estados Unidos, ainda que o modelo tenha sido privado e comercial, o Estado implantou regras e regulações de ordem pública para impedir, no linguajar do liberalismo, a captura — na semântica da social-democracia o termo seria "colonização" - da agenda pública de debates por interesses privilegiados.

Foi assim que surgiu a agência reguladora FCC (Federal Communications Commission), em 1934, para impedir formas sutis ou ostensivas de monopólio nos meios de comunicação. Os objetivos centrais da FCC são garantir, no plano político, a pluralidade de vozes e, no plano econômico, a concorrência saudável entre as diversas empresas do setor. As pessoas se perguntam por que, por exemplo, nos Estados Unidos, se firmaram três redes nacionais de televisão aberta (NBC, $\mathrm{CBS}$ e $\mathrm{ABC}$ ). A resposta é muito simples: elas são três porque a lei, por meio da FCC, assim obrigou. $\mathrm{O}$ mercado realizava, pois, um projeto público. Com base nesses e outros propósitos, a FCC vem inibindo oligopólios e monopólios, com as adaptações que os tempos requerem, conforme as mudanças de padrão tecnológico ${ }^{4}$.

O princípio geral, no entanto, tem sido preservado. Se um só grupo econômico se move para açambarcaro controle das principais estações de rádio e TV numa determinada região, além de veículos impressos importantes, ele deve encontrar limites às suas pretensões, em nome do interesse público. A razão é simples. Caso alcance seu objetivo, o grupo poderá adquirir um predomínio indesejável sobre a condução do debate público, o que conspira contra a diversidade de vozes e também contra a concorrência comercial. É por isso que se costuma dizer que as legislações antitruste, aplicadas às comunicações, protegem a boa prática da concorrência e a livre formação da opinião pública.

Dessa forma, também nos Estados Unidos, a despeito da tradição comercial do setor, as regras públicas estiveram postas desde o início, ajudando a proteger o espaço público dos riscos da concentração de audiência e de mercado, o que contribuiu para preservar, também, em alguma medida, o princípio do caráter público dos debates e das manifestações culturais que têm lugar na esfera pública.

Ao mesmo tempo, a sociedade norte-americana reservou para as emissoras públicas alguns espaços cativos e de grande valor. As estações da PBS (Public Broadasting System) estão presentes em várias cidades, com programação e gestão tipicamente não comerciais e não 
governamentais. O grande destaque da temporada, porém, é a NPR (National Public Radio), cuja audiência, numa rede colaborativa que se aproxima de mil emissoras de rádio espalhadas por todo o país, cada qual com sua própria grade autônoma, já atinge a marca superior a 30 milhões de ouvintes. Mesmo com a crise que se abateu sobre as redações dos Estados Unidos nos últimos anos, a NPR ampliou sua influência, com jornalismo independente sobre temas de interesse geral5.

\section{MERCADO E DEMOCRACIA: POR QUE A REGULAÇ̃̃O REFORCA A LIBERDADE}

Os casos europeu e norte-americano demonstram de modo cristalino que, no mundo da comunicação social, os riscos potenciais de contradição entre mercado e democracia são um cenário conhecido de longa data, o que requer a presença de regras públicas. Tais riscos só podem ser contidos por marcos legais, que devem ao mesmo tempo regular o mercado e impedir a possibilidade de interferência estatal ou governamental nos conteúdos culturais e jornalísticos da programação.

A regulação democrática, nesse sentido, fortalece a liberdade; afasta a possibilidade de censura, não o contrário. Nos mercados de radiodifusão onde não há marcos regulatórios democráticos, a liberdade se fragiliza e as chances de interferência governamental ou estatal nos conteúdos da radiodifusão aumentam consideravelmente. Prova disso é o que se passa no Brasil, onde praticamente todas as emissoras públicas, durante todo o tempo, ficam expostas aos interesses e, mais ainda, aos caprichos de autoridades públicas. Com o perdão da expressão, as autoridades aqui deitam e rolam, em cima das emissoras públicas porque a lei não as impede.

Os marcos legais que restringem, em países democráticos, os monopólios e a extensão da propriedade cruzada dos meios de comunicação fazem parte de um sistema lógico. Esse sistema costuma incluir, também, o veto à fusão entre radiodifusão e igrejas - se o Estado é laico, os serviços públicos concedidos pelo Estado a particulares (como as emissoras de rádio e TV) também devem primar pela laicidade, de sorte que as religiões podem aparecer na programação, mas não podem ser proprietárias de emissoras ou de redes - e a regulamentação de um espaço bem demarcado para a radiodifusão pública, definindo em termos práticos e verificáveis os marcos da independência perante o governo, o Estado e o mercado.A legislação democrática que coíbe os oligopólios é a mesma que protege a radiodifusão pública dos tentáculos do poder. Não se trata de fenômenos separados.

Também por isso marcos legais inspirados nos valores que regem esse campo na Europa e nos Estados Unidos são imprescindíveis à democracia brasileira. Eis aqui uma fatura que ainda não foi quitada pelos governos e legislaturas até hoje.Assim como ocorre na Europa,e
[5] Há vários registros desse crescimento. Entre eles, ver Downie Jr., Leonard e Schudson, Michael. "The reconstruction of American Journalism". Columbia: Universidade de Columbia, 2009, pp. 33ss, em <https:// stgcms.journalism.columbia.edu/cs/ BlobServer?blobheadervalueo $=$ inlin e;+filename\%3DReconstruction+of +Journalism.pdf\&blobcol=urldata\& blobtable=MungoBlobs\&blobheade rnameo $=$ Content - Disposition\&blob key=id\&blobwhere $=1212611716639$ \&blobheader=application/pdf $>$. 
[6] AConstituição Federal, no artigo 223, determina que a radiodifusão observará a "complementaridade dos sistemas público, estatal e privado", mas até hoje, como é reiterado constantemente nas discussões a respeito, esse e outros dispositivos da Carta Magna não foram regulamentados. Em geral, na cultura dos legisladores e dos gestores públicos, não há clareza sobre o que diferenciaria o "sistema estatal" do "sistema público", não sendo difícil prever que a regulamentação desse dispositivo será no mínimo árdua, assim como a regulamentação do parágrafo 5 do artigo 220, que estabelece: "Os meios de comunicação social não podem, direta ou indiretamente, ser objeto de monopólio ou oligopólio". mesmo nos Estados Unidos, a legislação nos ajudaria a demarcar com mais clareza o lugar e a função complementar da radiodifusão pública (em relação à comercial) em nosso país ${ }^{6}$.

\section{NATUREZA, DINHEIRO E GESTÃO}

Em síntese, o conceito de emissora pública constitui-se a partir de três pré-requisitos que devem ser observados.

Em primeiro lugar, a natureza jurídica da instituição, que absolutamente não pode ser propriedade particular.Admite-se, em virtude das características do ordenamento jurídico brasileiro, que figuras jurídicas como fundações (regidas pelo direito privado), Oscips (Organizações da Sociedade Civil de Interesse Público) e Ongs (Organizações Não Governamentais) supram a função da natureza jurídica de emissoras públicas. Mas a instituição não pode ser comercial, não deve ter o lucro por finalidade, nem estar sujeita à interferência governamental. Ela pode até ser estatal — como, por exemplo, as universidades -, desde que sua gestão esteja inteiramente protegida de ingerências do poder Executivo.Apesar disso, o modelo de órgão estatal está longe de ser o mais indicado.

Em segundo lugar, há o pré-requisito do financiamento. Este deve ter, também, caráter público. Pode vir de fundos públicos ou privados, desde que expressamente desvinculados de interesses - mediatos ou imediatos - governamentais ou comerciais; pode vir de uma taxa cobrada de cada domicílio com TV por força de lei, como acontece com a BBC; pode vir também de donativos ou de outras contribuições voluntárias, como acontece com a PBS (Public Broadcasting Service) ou a NPR nos Estados Unidos; pode vir ainda, no todo ou em parte, até mesmo do erário, desde que esteja livre da possibilidade de contingenciamentos - que se traduzem em pressão sobre a gestão editorial da instituição - e fora do alcance de atos discricionários dos gestores da máquina estatal. O que mais conta, aqui, é que a origem do dinheiro não se reflita, nem mesmo indiretamente, na orientação editorial da emissora, para que interesses particulares (partidários, familiares, religiosos, empresariais ou de movimentos sociais mais ou menos organizados) não exerçam pressão sobre a definição da pauta jornalística e da programação em geral. Para ser pública, o pré-requisito do financiamento de caráter público precisa ser atendido, desvinculado de pressões oriundas do Estado ou do mercado.

Em terceiro lugar, o que define o caráterverdadeiramente público de uma emissora de radiodifusão é a gestão independente. Ou seja, a gestão administrativa, financeira e editorial deve se dar segundo critérios e parâmetros autônomos, não devendo prestar contas à vontade política das autoridades ou ao apetite por audiência tão próprio do mercado. 
É só a partir desses pressupostos que podemos iniciar uma discussão sobre a programação propriamente dita. Eles são, pois, a condição prévia para que a entidade esteja preparada para pensar, conceber, planejar, produzir e pôr no ar uma programação de caráter verdadeiramente público. No caso brasileiro, que mais nos interessa aqui, o problema não está na avaliação da grade ou dos programas exibidos, mas justamente incide sobre tais pré-requisitos.

\section{E NO BRASIL?}

No Brasil, não há emissora pública realmente independente. Todas, e elas são muitas e diversas, submetem-se, raramente com elegância, mais raramente ainda com discrição, e no mais das vezes com desfaçatez, às idiossincrasias da autoridade.

Os dois casos emblemáticos nesse sentido são a TV Cultura de São Paulo e a TV Brasil, ligada ao governo federal. A primeira é, de longe, o nosso melhor exemplo de emissora pública. É a única que possui um conselho curador que efetivamente elege o presidente executivo da instituição. Em suas quatro décadas de existência, a TV Cultura ofereceu à sociedade, em vários momentos, uma programação de alta qualidade e que, por isso, atraiu expressivos contingentes de audiência. Ainda hoje,é o que de melhor temos nesse campo.

De dois anos para cá, ela vem sendo seguida de perto pela TV Brasil. As duas, no entanto, direta ou indiretamente, padecem de vulnerabilidades estruturais advindas da existência de vasos comunicantes que as vinculam ao poder Executivo.

$\mathrm{Na}$ TV Cultura, dos 44 membros do conselho curador, 22 são eletivos, três, vitalícios, dezoito, membros natos, e um representa os funcionários da instituição7. Em tese, essa proporção bastaria para impedir que a vontade dos membros natos, que são secretários de estado e reitores de universidades públicas e privadas, entre outros - alguns deles ligados ao governador ou exercendo cargos para os quais contaram com a nomeação do governador - pudesse definir as deliberações do conselho. Na prática, porém, embora eles sejam minoritários, a liderança do governo é decisiva. O histórico das principais decisões do conselho comprova que, de um modo ou de outro, em momentos agudos, a posição prevalecente é aquela patrocinada pelo governo paulista. Assim foi assim com a escolha de todos — sem exceção — os presidentes da instituição; assim ocorre com a escolha dos membros eletivos. É raro e bastante improvável, embora não impossível, que um nome que desagrade ao Executivo estadual seja conduzido ao conselho curador da Fundação Padre Anchieta.

Em termos estritamente formais, o conselho curador é autônomo. Seus membros eletivos são majoritários, e ele elege de fato e de direito
[7] Os eletivos são escolhidos pelo próprio Conselho; os vitalícios são Jorge da Cunha Lima, Lygia Fagundes Telles e Fabio Magalhães; os natos são secretários de Estado ou município, reitores de universidades, entre outros. 
o presidente da instituição - que não responde ao governador, mas ao próprio conselho. E isso nãoé pouco, trata-se de um marco importante em relação à ideia de autonomia. A TV Cultura de São Paulo (estado que também possui a Univesp TV, além de emissoras de rádio em AM e FM) é sem dúvida a mais independente e a mais influente emissora pública do país. Mas ainda assim, na prática, tal independência apresenta limitações.

Limites ainda maiores podem ser observados na Empresa Brasil de Comunicação (EBC), que resultou da fusão da Radiobrás com a TV-E do Rio de Janeiro, em 2008. A EBC é mais conhecida hoje pela televisão que levou ao ar, a TV Brasil. Se comparada às duas emissoras que lhe deram origem, ela é bem mais avançada como entidade de comunicação pública, embora esteja ainda muito submetida ao poder estatal.

Criada pela lei 11.652, de 7 de abril de 2008 , a EBC conta com a presença de dois conselhos em sua gestão: o conselho de administração e o conselho curador. Há, ainda, o conselho fiscal, que não tem função ativa na condução da entidade, cuidando, como é de praxe, apenas da verificação e da aprovação das contas e da legalidade dos atos de gestão. O poder de fato reside no consel ho administrativo, que elege - ou pode destituir - os seis diretores da empresa. O diretor-presidentee diretor geral, por sua vez, são escolhidos diretamente pelo presidente da República. No entanto, os cinco membros do conselho de administração são indicados pelo poder Executivo (ministérios ou pelo próprio presidente da República).

O conselho curador é composto por 22 integrantes, todos eles também designados pelo presidente da República. Suas atribuições são mais consultivas do que efetivas. Aprova anualmente o plano de trabalho e a linha editorial da EBC, além de acompanhar e fiscalizar a veiculação da programação. Mas tem poder para, por deliberação da maioria absoluta de seus membros, emitir voto de desconfiança à diretoria ou a um de seus diretores. A segunda advertência resultará necessariamente em afastamento do diretor em questão ou, se for o caso, de toda a diretoria.

Apesar de ter uma estrutura muito mais pública do que suas antecessoras, a EBC ainda está vulnerável às vontades do Planal to. Isso não quer dizer que ela seja cotidianamente instrumentalizada pelo poder, mas sua estrutura confere à presidência da República os meios para constrangê-la, pressioná-la e enquadrá-la em finalidades de propaganda, quando, é claro, existe tal intenção. Se o presente governo não se vale desses meios, não tem como garantir que, no futuro, outros ocupantes do Planalto exerçam esse tipo de poder.

A EBC está vinculada à Secretaria de Comunicação Social da Presidência da República(Secom), cujo ministro conserva a prerrogativa de indicar o presidente do conselho de administração, que, como vimos,é 
o órgão superior de direção da estatal. Esse vínculo institucional com a presidência da República vai na contramão das melhores práticas da comunicação pública, conforme a tradição europeia, segundo a qual as emissoras públicas devem ter afinidade com a área da cultura e não com os órgãos encarregados de promover a imagem do presidente da República. Nos países em que as emissoras públicas tiveram êxito, elas são consideradas entidades culturais que guardam vínculos indiretos com ministérios ligados à cultura.

ASecom nãoéum organismo com finalidades culturais; tem como objetivo primeiro a gestão da imagem da presidência da República. Ela gerencia a publicidade do governo - compra espaço publicitário nos meios de comunicação privados - e cuida da assessoria de imprensa do presidente. Sua meta é difundir uma imagem favorável do chefe de Estado e de governo, o que caracteriza comunicação de governo, não comunicação pública.

O vínculo da EBC com a Secom, portanto, não poderia ser mais impróprio, uma vez que este órgão não tem nada a ver com cultura em sentido amplo ou com a atividade jornalística em sentido estrito. Dedicado à assessoria de imprensa, não deveria supervisionar uma empresa pública encarregada de informar com objetividade e isenção.

Os propósitos e os métodos da assessoria de imprensa - em órgãos públicos ou privados - não são compatíveis com os propósitos e os métodos do jornalismo. Existe uma oposição natural e de fundo entre o papel de difundir versões oficiais e o papel de informar o cidadão com objetividade. Tanto que, nesse ambiente, é bastante improvável que um jornalismo independente e crítico possa encontrar terreno fértil.

Com base no exame do que acontece na TV Cultura e da TV Brasil, a conclusão de que não temos radiodifusão pública entre nós é evidente. Isso não significa que não estejamos caminhando nessa direção. Significa apenas que esse é um caminho tortuoso, traiçoeiro, e que há mais por fazer do que normalmente se admite.

Com efeito, no país existem outras emissoras que se dizem públicas, porém, com base nas definições aqui estabelecidas, não podem ser assim consideradas. Numa estimativa preliminar, sujeita às imprecisões próprias do setor (como aquelas que caracterizam de modo contumaz o Ministério das Comunicações), em 2009, contavam-se 147 emissoras educativas no Brasil. A soma, porém, não é confiável. Há, no conjunto, emissoras realmente educativas e outras que são educativas apenas na fachada. As que importam para a discussão aqui empreendida, contudo, são outras. Num levantamento realizado em 2006 pelo Ministério da Cultura, por ocasião do I Fórum Nacional de TVs Públicas, a Associação Brasileira de Emissoras Públicas, Educati- 
[8] Ver Vários autores. I Fórum $\mathrm{Na}$ cional de TV's Públicas: Diagnóstico do Campo Público de Televisão. Brasília: Ministério da Cultura, 2006.

[9] Ver 〈http://www.abepec.com.br〉.

[10] Esses dados são de 2006. O número de TVs Universitárias do Brasil pode ser consultado no site da Associação Brasileira de TVs Universitárias (ABTU): <http://www.abtu.org. br>. Já o levantamento das emissoras comunitárias foi feito pela Frenavatec - Frente Nacional pela Valorização das TVs do Campo Público, e pode ser consultado em 〈http://frenavatec. org/index.html>. O número de TVs Legislativas está no site da Associação Brasileira TVs e Rádios Legislativas - Astral (〈http://www.astralbrasil. org/associados.asp〉). Estão associadas à Astral apenas treze emissoras legislativas municipais. Levantamento feito em 2006 por Maria Lourdes dos Santos indicou que esse número, na realidade, era de 49 emissoras (Santos. "Breve história da TV legislativa no Brasil: raízes e origens". Trabalho apresentado no Congresso Brasileiro de Ciências da Comunicação, 2006. Brasília/São Paulo: Anais Eletrônicos/Intercom, 2006.

[11] Para uma versão mais extensa dese tema, ver "A TV Pública não faz, não deveria dizer que faz e, pensando bem, deveria declarar abertamente que não faz entretenimento", artigo publicado em I Fórum Nacional de TV's Públicas - Caderno de Debates n. 1. Brasília: Ministérioda Cultura,2006,pp13-20. As bandeiras que são elencadas nesse tópico se valem de uma transcrição de trechos do artigo citado. vas e Culturais (Abepec) informou a existência de dezenove estações geradoras, entre elas a TV Cultura de São Paulo, a TV E do Rio Grande do Sul e a Rede Minas 8 . Ao todo, essas estações multiplicavam-se em 2.880 retransmissoras. Atualmente, a Abepec contabiliza 22 filiados 9. Há ainda 52 canais universitários e outros 63 canais comunitários, transmitidos, em sua grande maioria, por sistemas de televisão por assinatura. Uns e outros declaram-se públicos, mas não atendem, de modo geral, aos pré-requisitos da comunicação pública tal como foram enumerados aqui. Os canais universitários, muitas vezes, atuam como veículo de promoção das universidades a que pertencem.

É preciso listar, também, nesse conjunto, as TVs Legislativas: duas no âmbito federal (TV Câmara e TV Senado), que contam com sinais abertos em algumas localidades, mas são vistas em geral nos serviços de TV por assinatura; dezessete no âmbito estadual e 49 na esfera municipa ${ }^{10}$. Tanto essas como a TV Justiça, pertencente ao Supremo Tribunal Federal, não contam com conselhos independentes, mas se subordinam funcional e diretamente às cúpulas dessas casas. A TV Câmara e a TV Senado respondem às mesas da Câmara e do Senado, respectivamente. A TV Justiça é controlada diretamente pela presidência do STF. Todas elas estão a serviço da divulgação desses órgãos, não a serviço da fiscalização deles pela sociedade. Não são, por isso, emissoras públicas.

\section{ALGUMAS PALAVRAS SOBRE PROGRAMAÇÃo"}

Se há, na bandeira da independência, uma plataforma ética a unificar a causa da TV Pública,é possível listar cinco bandeiras estéticas que também devem ser observadas. Importa, aqui, ter clareza de que, apenas quando a independência é compreendida, demarcada e praticada, o tema da programação se apresenta ao alcance da televisão pública. Essas bandeiras estéticas serão discutidas a seguir.

\section{Almejar o invisivel}

O sujeito só vê o objeto ao qual sabe dar nome. No olhar, só ganha visibilidade o que tem lugar na linguagem. O objetivo permanente da televisão pública deve ser o de furar o pano da visibilidade, que embrulha como um invólucro o que chamamos de realidade. Aqui é que se inscreve o dever da experimentação de linguagem.

Almejar o invisível significa não compactuar com a ilusão essencial do entretenimento, que é a de apoiar no visível o critério da verdade. O visível não é - nem contém - o critério da verdade. $\mathrm{O}$ visível é algo que nos fala aos sentidos, mas o conhecimento, a razão, o entendimento e a expressão das ideias estendem-se para além das fronteiras do visível. 
A televisão pública não deve se contentar com figuras, cenas, imagens, mas fundamentalmente com ideias em curso, em movimento. Para almejar o invisível é preciso sair da postura de ser bajulador de plateias, queé uma das atitudes definidoras da indústria do entretenimento.

\section{Desmontar a oferta do gozo pré-fabricado}

A televisão pública deve problematizar o ciclo do gozo do olhar, a oferta central da indústria de entretenimento. Até mesmo - ou principalmente - as peças publicitárias centrais, mais do que mercadorias distantes, oferecem o gozo próximo, o prazer do consumo subjetivo da imagem que se antecipa ao ato social, material, de consumir. Desmontar essa oferta de gozo é oferecer o diferente, é deixar de insistir na reincidência de doses maiores das mesmas sensações.

\section{Buscar o conteúdo que não cabe na TV comercial}

Uma sociedade democrática precisa dos dois pratos da balança, a televisão comercial e a televisão pública. O que a televisão comercial faz a televisão pública não deve pretender fazer. Ao mesmo tempo, o que a televisão pública faz, se estiver centrada em sua missão, a comercial não consegue fazer. Essa bandeira prega a diferenciação. É preciso identificar onde está a forma de comunicação que a televisão comercial não pode fazer, porque é justamente aí, nesse ponto escuro, invisível, que deve ser instalado o pequeno farol da TV pública.

Quando a TV Pública insiste em copiar, de modo rebaixado, os modelos privados dominantes, ela ganha aquele ar de atração requentada, de espetáculo de segunda. Tentando fugir do que o senso comum chamaria de "chatice", ela se deixa levar pela tentação de ficar parecida com os padrões estéticos das redes comerciais e, aí, sim, acaba ficando insuportavelmente chata. Claro que ela não tem o intuito de construir uma programação enfadonha. Ao contrário, ela deve pressupor, nesse sentido, o risco necessário para ser inteiramente distinta dos meios privados.

\section{Emancipar em lugar de vender}

A TV pública não pode sucumbir ao impulso de se desejar desejada. Sua vocação é problematizar essa modalidade primitiva de sedução - ou de mendicância afetiva. Ela deve, sim, desmontar esse jogo sem saída e desmascarar as armadilhas. Sua proposta de comunicação é mais incerta, mais ingrata, mais provocativa — indispensável para a diversificação de linguagens. Ou será assim ou ela não conseguirá deixar de ser linha auxiliar da indústria, às vezes até lhe fornecendo produtos para a comercialização.

A televisão pública não quer público cativo como a televisão comercial. Ela não funcionará como cativeiro, mas como emancipadora. Seu sentido é tornar o sujeito suficientemente autônomo para, no li- 
mite, poder prescindir da televisão. $O$ pesadelo que atormenta a televisão comercial é que, um dia, as pessoas não precisem mais dela. A realização da TV pública pressupõe o contrário - a emancipação. Ela não teme a emancipação e por isso pode se diferenciar. Ela se realiza tal como o professor diante do aluno que alça voo próprio. Com essa proposta de pacto emancipador, ela atrairá mais gente, pois saberá corresponder a uma necessidade que se encontra em aberto, que a televisão comercial não consegue atender. Ao não querer prender a sua audiência, adotando outra atitude diante dela, a televisão pública terá, seguramente, mais audiência.

A televisão comercial pode até ser educativa, se encontrar caminhos para isso. A televisão pública é uma instituição que precisa produzir gente emancipada, liberta, crítica - e pode até se tornar um sucesso, se for radical no seu compromisso de emancipar. O negócio da televisão pública não éentretenimento e, indo mais longe, não é sequer televisão: é cultura, é informação, é liberdade. Para a televisão comercial, o meio é um fim em si. Para a pública, o meio é uma possibilidade em aberto.

Desvencilhar-se do medo do "chefe"

Os administradores da TV pública vivem amedrontados com a ideia de que vão perder público. Nada poderia ser tão alucinado: eles não podem perder o que não têm. Mesmo assim, vivem com medo de perder (ainda mais) audiência e de levar bronca dos chefes, os governantes. Eles não sabem que estes não são chefes de verdade; ao menos, não deveriam ser. Eles não sabem que só perdendo o medo do "chefe" é que deixarão de temer a falta de audiência - e aí, sem esse medo, é que atrairão verdadeiramente o público.

De resto, a falta de público não deveria assustá-los, pois tem sido a sua rotina. Para a TV pública, só um caminho é possível: não competir com a televisão privada; não copiá-la. Fora disso, ela até poderá prestar bons serviços para o entretenimento, mas não terá valor para a democracia, para a cultura e para os olhos que se abrem diante dela. Não terá valor.

PARA HAVER TV PÚBLICA, O MAIOR OBSTÁculo NÃo É LEGAL, MAS CULTURAL

A gestão é o ponto crítico da fase atual da nossa televisão pública, a qual envolve, mais precisamente, os três requisitos para a sua independência - natureza jurídica, padrão de financiamento e modo de gestão. Não há possibilidade de que o espírito da programação e do modo de proceder das equipes não decorra do modo de gestão. Os dados da administração - todos eles - devem ser transparentes, publicados diariamente na internet. Os critérios e as métricas (de qualidade editorial, desempenho etc.) só têm legitimidade quando 
compartilhados com o público. Os cargos não podem estar abertos às indicações políticas, mas devem ser preenchidos exclusivamente com base em qualificação, desempenho e perfil. Se possível, deve prevalecer o critério do concurso público, e ainda está por ser feito a esse respeito um programa de ação amplo e detalhado para que as emissoras públicas possam se reconciliar com a causa pública e a democracia. Não há, enfim, boa programação que não tenha como alicerce uma gestão de excelência, pública, eficiente e transparente.

Em suma,é possível fazer televisão pública no Brasil desde que haja uma mudança cultural sobre as diretrizes e os contornos desse tipo de instituição. A começar pelos políticos, que, sem exceção, entendem as emissoras públicas como extensão das assessorias de imprensa pessoal de governantes. $\mathrm{O}$ aparelhamento das ferramentas da comunicação pública é uma constante em governos à esquerda ou à direita do espectro político, sem variações. Naturalmente, a independência das emissoras públicas deveria estar inscrita em lei, o que só seria viável a partir de um pacto democrático no interior das casas legislativas. Até lá, o caminho será com certeza acidentado, talvez longo. Muito dinheiro público ainda vai escoar nesse rio que é um dos veios mais renitentes do patrimonialismo na política brasileira: os agentes políticos creem fervorosamente que, quando o patrimônio público éconstituído de antenas, estúdios, câmeras e microfones, pode ser usado sem cerimônia para fins partidários, familiares ou escancaradamente pessoais. Artigos como este aqui não mudam essa cultura.

EUGÊNIO BUCCI, jornalista, é professor da Escola de Comunicação e Artes da Universidade de São Paulo e do Curso de Pós-graduação (lato sensu) em Jornalismo da ESPM. Foi presidente da Radiobrás (2003-2007)

Recebido para publicação

em 25 de outubro de 2010.

\section{NOVOS ESTUDOS}

CEBRAP

88 , novembro 2010

pp. 5-18 